\title{
Isolation and Characterization of Thermophilic Enzymes Producing Microorganisms for Potential Therapeutic and Industrial Use
}

\author{
Hasnaa R. Temsaah ${ }^{1 *}$, Ahmed F. Azmy², Mai Raslan ${ }^{1}$, Amr E. Ahmed ${ }^{1}$ and \\ Walaa G. Hozayen ${ }^{1,3}$
}

${ }^{1}$ Biotechnology and Life Sciences Department, Faculty of Postgraduate Studies for Advanced Sciences (PSAS), BeniSuef University, Egypt. ${ }^{2}$ Microbiology and Immunology Department. Faculty of Pharmacy, Beni-Suef University, Egypt. ${ }^{3}$ Biochemistry Division, Chemistry Department, Faculty of Science, Beni-Suef University, Egypt.

\begin{abstract}
The need of extremophile enzymes is increased. Such enzymes had found their utility in bio-industries such as leather, food, animal feed, textiles, and in bioconversions and bioremediation. Screening of microorganisms producing enzymes from different areas of soil led to the isolation of $\mathbf{3 8}$ isolates, the isolates were plate-screened for their ability to produce extracellular enzymes. The promising strains were selected and screened for their enzyme thermostability and screened quantitatively for potential industrial and therapeutic applications. Tolerance of selected microorganisms was investigated to a varied range of $\mathrm{pH}$, salinity, and enzyme activity over a range of temperature. The genotypic identification of $16 \mathrm{~S}$ rDNA sequence of the promising strains revealed that our strains were Streptomyces mutabilis, Streptomyces ghanaensis, Streptomyces rochei and Enterobacter cloacae. The isolated microorganisms quantified as an effective producer of industrially important enzymes amylase, cellulase, esterase, casienase and therapeutic enzyme L-asparaginase. All enzymes produced from the four isolates show enzyme activity and stability at different high temperature $\left(60^{\circ} \mathrm{C}, 80^{\circ} \mathrm{C}, 100^{\circ} \mathrm{C}\right)$. The amylase shows optimum activity at $37^{\circ} \mathrm{C}$, while the other four enzymes show optimum activity at different high temperature $\left(60{ }^{\circ} \mathrm{C}, 80\right.$ $\left.{ }^{\circ} \mathrm{C}\right)$. The study shows that Streptomyces mutabilis produce acidophilic enzyme amylase, Streptomyces ghanaensis produce acidophilic enzyme cellulase and neutrophilic enzyme esterase, Enterobacter cloacae and Streptomyces rochei produce alkalophilic enzymes (L-asparaginase, caseinase) respectively. Enzymes show highest enzyme activity at high $\mathrm{NaCl}$ concentration (5 and $7.5 \%$ ).
\end{abstract}

Keywords: Microorganism, thermophilic enzymes, Streptomyces, Enterobacter.

*Correspondence: Hasnaa Temsaah, h_temsaah@yahoo.com; Ahmed Azmy, ahmed.abdelaziz@pharm.bsu.edu.eg

(Received: 09 September 2018; accepted: 16 October 2018)

Citation: Hasnaa R. Temsaah, Ahmed F. Azmy, Mai Raslan, Amr E. Ahmed and Walaa G. Hozayen, Isolation and Characterization of Thermophilic Enzymes Producing Microorganisms for Potential Therapeutic and Industrial Use, J Pure Appl Microbiol., 2018; 12(4):1687-1702. http://dx.doi.org/10.22207/JPAM.12.4.02

(c) The Author(s) 2018. Open Access. This article is distributed under the terms of the Creative Commons Attribution 4.0 International License which permits unrestricted use, sharing, distribution, and reproduction in any medium, provided you give appropriate credit to the original author(s) and the source, provide a link to the Creative Commons license, and indicate if changes were made. 


\section{INTRODUCTION}

Enzymes are defined as biocatalyst proteins in nature, which are produced by living cells to achieve specific biochemical reactions or forming parts of the metabolic processes of the cell. Enzymes are very specific in action on their substrates ${ }^{1}$. The role of enzymes had been known in many processes. The presence of these enzymes was associated with the ancient Greek history where enzymes were used from different microorganisms in baking, alcohol production, brewing, cheese making, pulp, detergents, textiles, paper, leather, pharmaceuticals, beverages, chemicals, biofuels, personal care, animal feed and other ${ }^{2}$. With better knowledge and purification of enzymes, there is an increase in number of applications, also the availability of thermostable enzymes, aids in having a number of new possibilities for industrial processes have emerged 3.

The main source of the commercially available enzymes are microorganisms, plants, and animals. The microorganisms are the major fraction of the commercially available enzyme producers. There is increasing need day by day for microbial enzymes due to their clean, costeffective, and eco-friendly application, in addition to their significance in many biotechnological processes, rapid growth rate, and ease of nutritional requirement ${ }^{4,5}$.

Finding extremophile microorganisms is one of the methods for obtaining enzymes with suitable properties for industrial applications. There are a few advantages in using thermostable enzymes in industrial processes compared to thermo-labile enzymes ${ }^{2}$. The main advantage is that as there is an increase in temperature of the process, the rate of reaction increases. $\mathrm{A} 10^{\circ} \mathrm{C}$ increase in temperature approximately doubles the reaction rate, which leads to decrease in the amount of enzyme needed ${ }^{6}$. The thermostable enzymes have tolerance to higher temperatures, which give a longer half-life to the enzyme. Using higher temperatures (above $60^{\circ} \mathrm{C}$ ) is also inhibitory to microbial growth, decreasing the probability of microbial contamination 7,8. The high-temperature enzymes also, help in reduction of the substrate viscosity during the progress of hydrolysis of substrates or raw materials and enhancing the mass-transfer in industrial processes ${ }^{9}$. For example; The industrial processes for cellulolytic enzymes are employed in the detergents causing color brightening and softening, bio stoning of jeans, the color extraction from juices, pretreatment of biomass containing cellulose to improve the nutritional quality of forage, and pretreatment of industrial wastes ${ }^{5}$.

However, in many cases, the substrates are artificial compounds in industrial processes, and enzymes, which catalyze suitable reactions for such processes, are still unknown. So, screening for novel enzymes capable of catalyzing new reactions is needed. In addition, the new enzyme discovery will provide evidence for designing new enzymatic processes. Screening a large number of microorganisms is one of the most successful and efficient means of finding new enzymes, because of their characteristic versatility and diversity. Such enzymes are useful catalysts for the synthesis of many biologically and chemically useful compounds ${ }^{10}$.

The objective of our study was to overview the enzymes produced by microorganisms, which had been extensively studied worldwide for their isolation and characterization of their specific properties. This required screening of various microbes from different sources for isolation of potential enzymes with novel properties of thermophilicity, thermostability, and resistant to different factors ( $\mathrm{pH}$, salinity).

\section{MATERIAL AND METHODS Sample Collection}

Soil samples were collected in sterilized bags from the depth of $40 \mathrm{~cm}$ from different sites; Garden, farms, and muddy soil in Beni-Suef governorate in Egypt.

\section{Chemicals}

Nessler's reagent, Tyrosin 99\%, Carboxy Methyl Cellulose (CMC), phenol red and foline phenol reagent were purchased from Sigma Aldrich, USA. All culture media and supplements (Tryptone Soya Broth (TSB), peptone, yeast) obtained from Oxoid, UK. All other chemicals are of analytical grade.

\section{Isolation of bacteria}

One gm of soil was emulsified in $10 \mathrm{ml}$ of sterile saline, vortexed well for 5 minutes.

All the samples were tenfold serially diluted in sterile saline. Serial dilutions were 
done up to $10^{-6}$ in ordered to get pure colonies 11. All the diluted samples were cultured on two plates of different culture media, inorganic salts starch agar (ISP4) media supplemented with cycloheximide $(100 \mu \mathrm{g} / \mathrm{ml})$ and colistin $(5 \mu \mathrm{g} /$ $\mathrm{ml}$ ) for Actinomycetes; and tryptone soya agar supplemented with cycloheximide $(30 \mu \mathrm{g} / \mathrm{ml})$ and penicillin $(100 \mu \mathrm{g} / \mathrm{ml})$ for Eubacteria.

Morphologically different colonies were selected. To obtain a pure culture, repetitive streaking was done. Pure cultures were isolated and preserved in glycerol stock cultures at $-20^{\circ} \mathrm{C}$ until further use.

Primary Screening of Enzymes Producing strains For primary screening of different enzymes, each isolate was cultured in minerals salt media amended with different substrates as a sole carbon source. Indeed, to screen for caseinase, skimmed milk was used as the carbon source while for esterase, amylase, cellulase L-asparaginase; tween 80 , starch, CMC and L-asparagine were used, respectively. Mineral salt medium contains $\left(0.025 \mathrm{~g} / \mathrm{L} \mathrm{KNO}_{3^{\prime}}, 0.1 \mathrm{~g} / \mathrm{L} \mathrm{KH}_{2} \mathrm{PO}_{4^{\prime}}\right.$ $0.05 \mathrm{~g} / \mathrm{L} \mathrm{MgSO}{ }_{4} .7 \mathrm{H}_{2} \mathrm{O}, 0.01 \mathrm{~g} / \mathrm{L} \mathrm{CaCl}_{2} .2 \mathrm{H}_{2} \mathrm{O}, 0.005$ $\mathrm{g} / \mathrm{L} \mathrm{FeSO} \mathrm{F}_{4} .7 \mathrm{H}_{2} \mathrm{O}, 15 \mathrm{~g} / \mathrm{L}$ Agar). The plates were incubated at $30^{\circ} \mathrm{C}$ for 5 days for Actinomycetes, and at $37^{\circ} \mathrm{C}$ for 24 hours for Eubacteria ${ }^{12}$. A growth of visible colonies indicated a probability of enzyme production.

Qualitative screening enzyme producing strains

All growing bacterial strains will be confirmed for enzyme production qualitatively with a method specified for each enzyme.

\section{Amylase activity}

Only positive colonies on starch plate in primary screening were selected and screened for amylase activity. Starch agar medium was used for isolation of starch-degrading bacteria. Medium composition was as follows: soluble starch (20 $\mathrm{g} / \mathrm{L})$, peptone $(20 \mathrm{~g} / \mathrm{L})$, agar $(20 \mathrm{~g} / \mathrm{L})$, and adjusted to $\mathrm{pH}$ 7.0. The plates were incubated at $30^{\circ} \mathrm{C}$ for 5 days for Actinomycetes, at $37^{\circ} \mathrm{C}$ for 24 hours for Eubacteria, and then plates were flooded with $1 \%$ Lugol's iodine reagent for 20 minutes and washed with water to remove the excess color. The zone of clearance indicated starch hydrolysis was selected as positive results. ${ }^{1,13,14}$

\section{Cellulase Activity}

Visible colonies grown on CMC plate in primary screening were screened by Spot plate method using $\mathrm{CMC}$ agar media consisting of yeast extract $(0.2 \% \mathrm{w} / \mathrm{v})$, peptone $(2 \% \mathrm{w} / \mathrm{v})$, $\mathrm{KH}_{2} \mathrm{PO}_{4}(0.1 \% \mathrm{w} / \mathrm{v}), \mathrm{Mg}_{2} \mathrm{SO}_{4} .7 \mathrm{H}_{2} \mathrm{O}(0.5 \% \mathrm{w} / \mathrm{v}), \mathrm{NaCl}$ $(0.075 \% \mathrm{w} / \mathrm{v})$, carboxymethycellulose $(0.2 \% \mathrm{w} / \mathrm{v})$ and nutrient agar $(1.5 \% \mathrm{w} / \mathrm{v})(\mathrm{pH} 6.8-7){ }^{15}$. The plates were incubated at $30^{\circ} \mathrm{C}$ for 5 days for Actinomycetes and at $37^{\circ} \mathrm{C}$ for 24 hours for Eubacteria. To visualize the positive cellulose hydrolysis zone, the plates were flooded with an aqueous solution of $0.1 \%$ Congo red for 15 minutes and washed with $1 \mathrm{M} \mathrm{NaCl}{ }^{5,16}$. Appearance of clear zones against dark brown around the colonies indicating cellulose hydrolysis.

L-asparaginase Activity

Growing colonies on the plate of L-asparaginase in primary screening were screened for L-asparaginase activity by rapid plate assay method using the modified Czapek Dox medium. Medium contain: $6 \mathrm{~g} / \mathrm{L} \mathrm{Na}_{2} \mathrm{HPO}_{4} ; 2 \mathrm{~g} / \mathrm{L} \mathrm{KH}_{2} \mathrm{PO}_{4} ; 5$ $\mathrm{g} / \mathrm{L} \mathrm{NaCl} ; 20 \mathrm{~g} / \mathrm{L}$ L-asparagine; $2 \mathrm{~g} / \mathrm{L}$ glycerol; 0.2 $\mathrm{g} / \mathrm{L} \mathrm{MgSO}-7 \mathrm{H}_{2} \mathrm{O} ; 0.005 \mathrm{~g} / \mathrm{L} \mathrm{CaCl}_{2} .2 \mathrm{H}_{2} \mathrm{O} ; 0.009 \%$ phenol red; $20 \mathrm{~g} / \mathrm{L}$ agar, $\mathrm{pH}$ 7. ${ }^{17}$. The plates were incubated at $30^{\circ} \mathrm{C}$ for 5 days for Actinomycetes and at $37^{\circ} \mathrm{C}$ for 24 hours for Eubacteria. A set of plates were also run as a control without L-asparagine. The pink zone around the colony indicates that the organism is able to produce L-asparaginase. ${ }^{18,19}$.

\section{Esterase Activity}

Esterase activity was done according to Ramnath method. Tween substrate plates were prepared as follows (g/L); $10 \mathrm{~g} / \mathrm{L}$ peptone, $5 \mathrm{~g} / \mathrm{L}$ $\mathrm{NaCl}, 0.1 \mathrm{~g} / \mathrm{L} \mathrm{CaCl} \cdot 2 \mathrm{H}_{2} \mathrm{O}, 20 \mathrm{~g} / \mathrm{L}$ agar and $10 \mathrm{ml} / \mathrm{L}$ (v/v) Tween 80. The plates were incubated for 5 days at $30^{\circ} \mathrm{C}$ for Actinomycetes strains and for 24 hours at $37^{\circ} \mathrm{C}$ for Eubacteria strains. The hydrolysis of tween result in release of free fatty acids, which bind with the calcium in the medium to form insoluble crystals around the point of inoculation and opaque colony appeared ${ }^{20}$.

\section{Caseinase Activity}

Colonies grown on skimmed milk plate in primary screening were screened for protease activity. The proteolytic activity of the colonies was screened on skimmed milk agar containing 1.5\% $(\mathrm{w} / \mathrm{v})$ skimmed milk. The plates were incubated at $30^{\circ} \mathrm{C}$ for 5 days for Actinomycetes and at $37^{\circ} \mathrm{C}$ for 24 hours for Eubacteria. Colonies showing a clear zone of skimmed milk hydrolysis were recorded as positive for protease production. ${ }^{21}$. 
Screening of the Enzymes Stability at different temperatures

The promising isolates (based on qualitative assay test) were cultured in the production media of each enzyme (described below). The organisms were harvested from the culture broth by centrifugation at $10.000 \mathrm{rpm}$ for 25 minutes at $4^{\circ} \mathrm{C}$ and the supernatants were used as sources of extracellular enzymes. Thermal stability of the enzymes was investigated by incubating the bacterial free supernatant at varied temperatures $\left(60^{\circ} \mathrm{C}-80^{\circ} \mathrm{C}-100^{\circ} \mathrm{C}\right)$ for 1 hour prior to standard quantitative enzyme assay.

\section{Quantitative Assay of enzymes}

The remarkable enzyme producer strains with a good thermal stability had been selected for quantitative assay.

\section{For Amylase}

Bacterial isolates were cultured in 100 $\mathrm{ml}$ volumes in $250 \mathrm{ml}$ Erlenmeyer flasks using a mineral salts medium supplemented with 10.0 $\mathrm{g} / \mathrm{L}$ soluble starch, $\mathrm{pH}$ of the medium was adjusted to $7.0 \pm 0.2$. The cultures were incubated with shaking at $150 \mathrm{rpm} / \mathrm{min}$. for 5 days at $30^{\circ} \mathrm{C}$ for Actinomycetes and at $37^{\circ} \mathrm{C}$ for $24 \mathrm{hr}$ for Eubacteria. The organisms were harvested from the culture broth by centrifugation at $10.000 \mathrm{rpm}$ for 25 minutes at $4^{\circ} \mathrm{C}$ and the supernatants were used as sources of extracellular amylases ${ }^{12}$.

Amylase assay was done as described by Bernfeld with some modifications ${ }^{22}$. Briefly; $0.5 \mathrm{ml}$ of $1 \%$ starch solution prepared in $0.1 \mathrm{M}$ phosphate buffer (pH 7.2) was added to $0.5 \mathrm{ml}$ of crude enzyme and incubated for $30 \mathrm{~min}$. at $37^{\circ} \mathrm{C}$. The reaction was stopped by adding $1 \mathrm{ml}$ of dinitrosalicysilic acid (DNS) reagent and kept on boiling water bath for $5 \mathrm{~min}$. The absorbance was measured at $540 \mathrm{~nm}$ against a blank without enzyme. One unit of enzyme activity is defined as the amount of enzyme that liberated one micromole of reducing sugar (glucose) per min. under assay conditions.

\section{For Cellulase}

Each isolate were inoculated in a conical flask containing $50 \mathrm{ml}$ of $\mathrm{CMC}$ broth $\left(0.2 \mathrm{~g} \mathrm{NaNO}_{3}\right.$, $0.12 \mathrm{~g} \mathrm{~K}_{2} \mathrm{HPO}_{4}, 0.01 \mathrm{~g} \mathrm{KH}_{2} \mathrm{PO}_{4} 0.05 \mathrm{~g} \mathrm{KCl}, 0.05 \mathrm{~g}$ $\mathrm{MgSO}_{4} .7 \mathrm{H}_{2} \mathrm{O}, 0.02 \mathrm{~g}$ yeast extract, $0.01 \mathrm{~g} \mathrm{Fe}\left(\mathrm{So}_{4}\right)_{3}$. $\mathrm{H}_{2} \mathrm{O}, 1 \mathrm{~g} \mathrm{CMC} \mathrm{in} 100 \mathrm{ml}$ of distilled water). After 5 days for Actinomycetes, 24 hours for Eubacteria, $10 \mathrm{ml}$ of each culture broth was withdrawn, centrifuged at $10.000 \mathrm{rpm}$ for $20 \mathrm{~min}$. at $4^{\circ} \mathrm{C}$. The supernatant was utilized for the determination of enzyme activities by the DNS (3,5-dinitrosalicylic acid) method ${ }^{23}$. Briefly, through the determination of the amount of reducing sugars liberated from carboxymethylcellulose (CMC) solubilized in 50 $\mathrm{mM}$ Tris $\mathrm{HCl}$ buffer, $\mathrm{pH}$ 7. the mixture of enzyme and substrate was incubated for $20 \mathrm{~min}$. at $37{ }^{\circ} \mathrm{C}$. and the reaction was stopped by the addition of DNS solution. The treated samples were boiled for $10 \mathrm{~min}$., cooled in water for color stabilization, and the optical density was measured at $550 \mathrm{~nm}$. The cellulase activity was determined by using a calibration curve for glucose. One unit of enzyme activity was defined as the amount of enzyme that released 1 micromole of glucose per minute ${ }^{24}$.

\section{For $L$ asparaginase}

For quantitative estimation of L-asparaginase, the modified Czapek Dox broth (mentioned before $)^{17}$ was used as the production medium. The samples were withdrawn after 5 days for actin and 24 hours for Eubacteria. Enzyme activity was checked by Nesseler's method.

The amount of enzyme that liberates $1 \mu \mathrm{mol}$ of ammonia per minute at $37^{\circ} \mathrm{C}$ equal to one unit of L-asparaginase ${ }^{25}$.

\section{For esterase}

Production of esterase was carried out in PYD broth medium containing $5 \mathrm{~g} / \mathrm{L}$ peptone; $3 \mathrm{~g} / \mathrm{L}$ beef extract; $5 \mathrm{~g} / \mathrm{L}$ sodium chloride; $5 \mathrm{~g} / \mathrm{L}$ yeast extract, $1 \mathrm{~g} / \mathrm{L}$ Dextrose and $10 \mathrm{ml} / \mathrm{L}$ olive oil ${ }^{26}$. A titrimetric method used for qualitative determination of Esterase enzyme. Indeed, 1\% substrate (olive oil) is titrated against $10 \mathrm{mM} \mathrm{NaOH}$. Using the following formula Esterase activity can be calculated.

Esterase activity $=\underline{\text { Volume of } \mathrm{NaOH} \text { consumed }(\mathrm{ml}) * \text { Molarity of } \mathrm{NaOH}}$ The volume of enzyme (ml) * Reaction time (min.)

One unit of esterase activity is the amount of enzyme that liberates $1 \mathrm{mmol}$ of fatty acid per minute at $30^{\circ} \mathrm{C}$ at pH 7 under the assay conditions 28.

\section{For caseinase}

Protease was produced in an optimized production medium of $\mathrm{pH} 8.0$ containing $1 \%$ galactose, $0.5 \%$ casein, $0.55 \%$ peptone, $0.2 \%$ $\mathrm{KH}_{2} \mathrm{PO}_{4}, 1 \% \mathrm{Na}_{2} \mathrm{CO}_{3}$ and $0.2 \% \mathrm{MgSO}_{4} \cdot 7 \mathrm{H}_{2} \mathrm{O}{ }^{29}$. Protease activity was measured by using casein as a substrate. The assay consists of $0.5 \mathrm{ml}$ of $1 \%$ 
aqueous casein solution, $1.25 \mathrm{ml}$ tris buffer $(\mathrm{pH}$ 7.2 ), and $0.25 \mathrm{ml}$ supernatant of bacteria. Negative control was done by adding all reagents without bacterial supernatant. The reaction was incubated at $30^{\circ} \mathrm{C}$ for $30 \mathrm{~min} .3 \mathrm{ml}$ of $5 \%$ Trichloro Acetic acid (TCA) was added and placed at $4^{\circ} \mathrm{C}$ for $10 \mathrm{~min}$. to precipitate. Centrifuge at $10.000 \mathrm{rpm}$ for $15 \mathrm{~min}$. $0.5 \mathrm{ml}$ of the supernatant was taken and $2.5 \mathrm{ml}$ of $0.5 \mathrm{M}$ sodium carbonate was added, mixed well and incubated at room temperature for $20 \mathrm{~min}$. Then $0.5 \mathrm{ml}$ of folin phenol reagent was added and the absorbance was read at $660 \mathrm{~nm}$ using spectrophotometer ${ }^{30}$.

One unit of protease activity is equal to the amount of enzyme required to liberate 1 microgram tyrosine per milliliter in $1 \mathrm{~min}$. under the experimental conditions used ${ }^{30}$.

Units $/ \mathrm{mL}$ enzyme $=$ micromole tyrosine equivalents released $\times$ total volume of assay) $\div$ (Volume of enzyme used $x$ time of assay $\times$ volume used in colorimetric determination

\section{Optimization of temperature, $\mathrm{pH}$ and salinity for the enzyme activity}

Optimal conditions for enzyme activity were measured at different parameters.

\section{a) Temperature}

Effect of temperature on enzyme activity was examined by performing the enzymatic reaction at different temperatures ranging at $37^{\circ} \mathrm{C}$, $60^{\circ} \mathrm{C}$ and $100^{\circ} \mathrm{C}$ under standard assay condition. b) $\quad \mathrm{pH}$

Effect of $\mathrm{pH}$ on enzyme activity was investigated by testing the enzyme assay at different $\mathrm{pH}$ ranging from 5 to 9 by using the following buffer systems: $0.1 \mathrm{M}$ sodium acetate ( $\mathrm{pH} 4-5.5) ; 0.1 \mathrm{M}$ sodium phosphate ( $\mathrm{pH}$ 6-7.5); $0.1 \mathrm{M}$ glycine $\mathrm{NaOH}$ (pH 9.5-12) under standard assay condition ${ }^{22}$.

c) Salinity

Effect of Salinity on enzyme activity was studied by measuring enzyme activity at different $\mathrm{NaCl}$ concentration $(0 \%, 5 \%, 7.5 \%)$ under standard assay condition

\section{S rDNA and phylogenetic analysis}

Genomic DNA extraction was done using GeneJET Plant Genomic DNA Purification Kit for Actinomycetes and GeneJET Genomic DNA Purification Kit (Thermo Fisher Scientific, USA) for Eubacteria. PCR was run to amplify 16S rDNA gene (Thermo Fisher Scientific, USA) with the following set of bacterial primers $8 \mathrm{~F}$ (5-AGAGTTTGATCCTGGCTCAG-3) and $1492 \mathrm{R}$ (5-CGGTTACCTTGTTACGACTT-3). Amplification was carried out in a $50 \mu \mathrm{l}$ reaction volume. The thermal cycle steps were applied as follows: initial denaturation at $95{ }^{\circ} \mathrm{C}$ for $5 \mathrm{~min}$, followed by 35 cycles of $1 \mathrm{~min}$. denaturation at $95^{\circ} \mathrm{C}, 1 \mathrm{~min}$. primer annealing at $48{ }^{\circ} \mathrm{C}, 1.5 \mathrm{~min}$. extension at $72{ }^{\circ} \mathrm{C}$ and a final $10 \mathrm{~min}$. extension at $72^{\circ} \mathrm{C}$. PCR product was purified and sequenced at Macrogen, Korea.

Nucleotide sequences were blast analyzed with NCBI database ${ }^{31}$. Phylogenetic tree was constructed using the neighbor joining method 32 with bootstrap method as a test of phylogeny with 500 bootstrap replication ${ }^{33}$ and Kimura 2parameter model ${ }^{34}$ in the Molecular Evolution Genetic Analysis (MEGA) software version $6{ }^{35}$.

Statistical Analysis

Results shown in this study are the means of three independent determinations. Standard deviations for each of the experimental results were calculated using Microsoft Excel software and represented as error bars.

\section{RESULTS}

Sample Collection and Pretreatment

From 10 soil samples, a total 38 strains were isolated. Based on the morphological and biochemical characteristics, the isolates were

Table 1. Primary enzymatic screening of different extracellular enzymes produced from different Actinomycetes and Eubacteria isolates.

\begin{tabular}{lcccccc}
\hline & Total & Caseinase & Amylase & Esterase & Cellulase & L-asparaginase \\
\hline Actinomycetes & 26 & 8 & 5 & 17 & 12 & 8 \\
Eubacteria & 12 & 9 & 6 & 11 & 9 & 4 \\
Total & 38 & 17 & 11 & 28 & 21 & 12 \\
\hline
\end{tabular}


Temsaah et al. J Pure Appl Microbiol, 12(4), 1687-1702 Dec. 2018 | http://dx.doi.org/10.22207/JPAM.12.4.02

Table 2. Distribution of enzyme producing microorganisms isolated from soil

\begin{tabular}{|c|c|c|c|c|c|c|}
\hline & Strains & Caseinase & Esterase & Amylase & Cellulase & L-asparginase \\
\hline \multirow[t]{16}{*}{ Actinomycetes } & 1 & - & + & - & - & + \\
\hline & 2 & + & - & - & + & - \\
\hline & 3 & - & + & - & - & + \\
\hline & 4 & - & + & - & - & - \\
\hline & 5 & - & - & - & - & + \\
\hline & 6 & - & + & - & - & - \\
\hline & 7 & - & + & - & + & - \\
\hline & 8 & + & - & - & + & - \\
\hline & 9 & - & - & + & - & - \\
\hline & 10 & - & + & - & - & - \\
\hline & 11 & - & - & + & - & + \\
\hline & 12 & - & + & - & + & - \\
\hline & 13 & + & - & - & - & - \\
\hline & 14 & + & - & + & + & - \\
\hline & 15 & - & + & - & - & + \\
\hline & 16 & - & + & - & + & - \\
\hline \multirow[t]{12}{*}{ Eubacteria } & 17 & + & + & - & - & - \\
\hline & 18 & + & + & - & - & + \\
\hline & 19 & + & + & - & - & - \\
\hline & 20 & - & + & + & + & - \\
\hline & 21 & - & + & + & + & - \\
\hline & 22 & + & - & - & - & + \\
\hline & 23 & + & - & + & - & + \\
\hline & 24 & - & + & - & + & - \\
\hline & 25 & - & + & - & + & + \\
\hline & 26 & - & + & + & - & - \\
\hline & 27 & + & - & - & + & - \\
\hline & 28 & + & + & - & + & - \\
\hline \multirow[t]{11}{*}{ Actinomycetes } & 29 & - & + & - & - & + \\
\hline & 30 & + & - & - & + & - \\
\hline & 31 & - & + & - & - & + \\
\hline & 32 & - & - & + & + & - \\
\hline & 33 & - & + & - & - & + \\
\hline & 34 & - & + & - & - & - \\
\hline & 35 & + & - & + & + & - \\
\hline & 36 & - & + & - & - & - \\
\hline & 37 & + & - & - & - & - \\
\hline & 38 & - & + & - & + & - \\
\hline & Total & 14 & 24 & 9 & 16 & 12 \\
\hline
\end{tabular}

identified as 26 Actinomycetes and 12 Eubacteria. Primary screening of each enzyme producing strain

Bacteria grown in primary screening on plates containing the enzyme substrate as the only carbon source indicate probable positive production of the enzyme.

Among the 38 bacterial isolates, 17 isolates showed a caseinase activity, 11 isolates showed amylase activity, 28 isolates showed esterase activity, 17 isolates showed cellulase activity and 12 isolates identified as L- asparaginase producers as shown in table 1.

\section{Qualitative screening}

The probable positive strains from primary screening were confirmed for the production of enzymes using specified media. It was found that the strains with positive qualitative screening for caseinase enzyme were 14 , for amylase activity were 9 , for esterase activity were 24 , for cellulase 


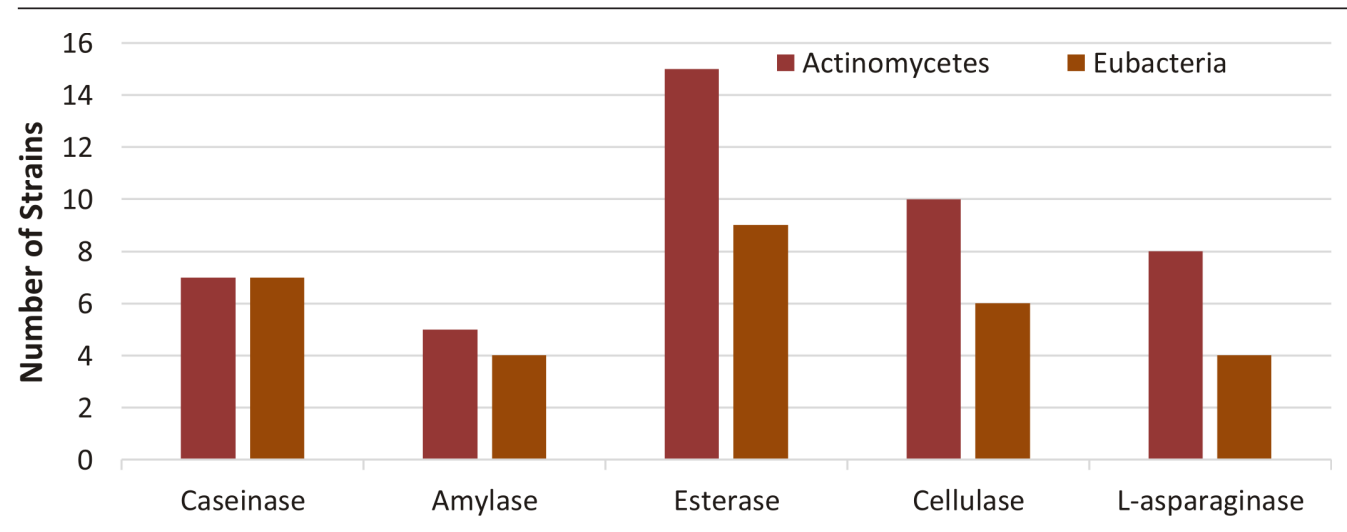

Fig. 1. Distribution of enzyme producing strains isolated from soil samples based on confirmatory qualitative assay test.

These 4 isolates secret the 5 enzymes in high amount

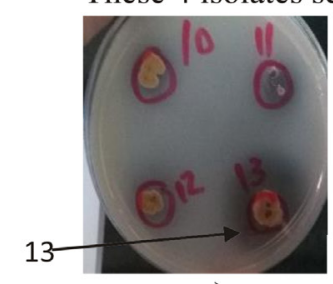

a)

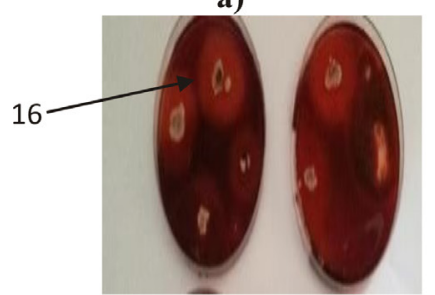

d)

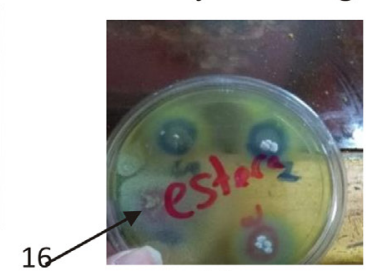

b)

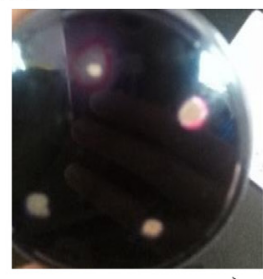

c)

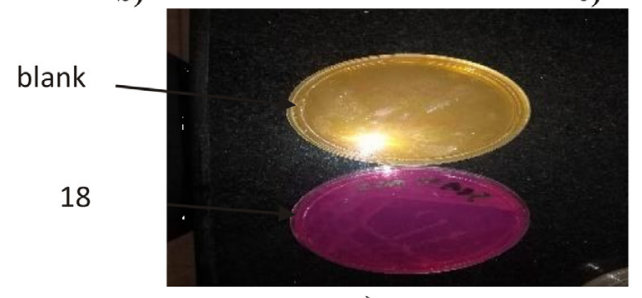

e)

Fig. 2. Qualitative screening of different enzymes in different isolates

(a: skimmed milk agar indicates a clear zone around the colony for caseinase producing microorganisms, b: Tween substrate plates showed insoluble crystals around the colony and opaque colony indicate esterase positive strains, c: starch plate indicate clear zone against dark blue on the plate for positive amylase strains, d: CMC Agar plates show clear zones against dark brown around the colonies indicating cellulose hydrolysis, e: Czapek Dox show pink coloration for cultures indicate positive production of Lasparaginase with blank (yellow in color). Arrows and numbers show the isolates with largest enzyme activity and their numbers.

activity were 16 , and for L-asparaginase were 12 as shown in table 2 and Fig. 1.

Among the obtained isolates, based on the area of the zone around the colony (bigger zone indicates more enzyme production) and the thermal stability (Fig. 4). Four strains were selected for further investigation as shown in Fig. 2.

Genotypic characteristics of the isolates and the phylogenetic tree

Based on 16S rDNA sequence analysis strain No. 14 was most closely related to Streptomyces mutabilis with similarity of $97 \%$, strain No. 16 was related to Streptomyces ghanaensis with similarity of $86 \%$, strain No. 18 was closely related to Enterobacter cloacae with similarity of $97 \%$ and strain No. 13 was closely related to Streptomyces rochei with similarity of $97 \%$.

Two phylogenetic trees were constructed by NCBI database; using $16 \mathrm{~S}$ rDNA sequences of strain no. 14, 16, 13 each compared with 5 different Streptomyces species, and other for $16 \mathrm{~S}$ rDNA sequences of strain No. 18 compared with 5 different eubacteria. 

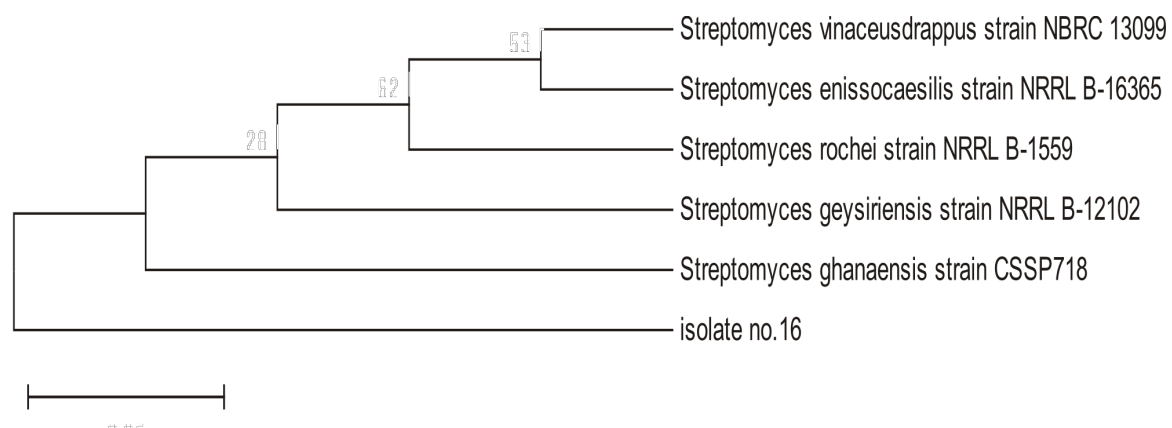

(a)

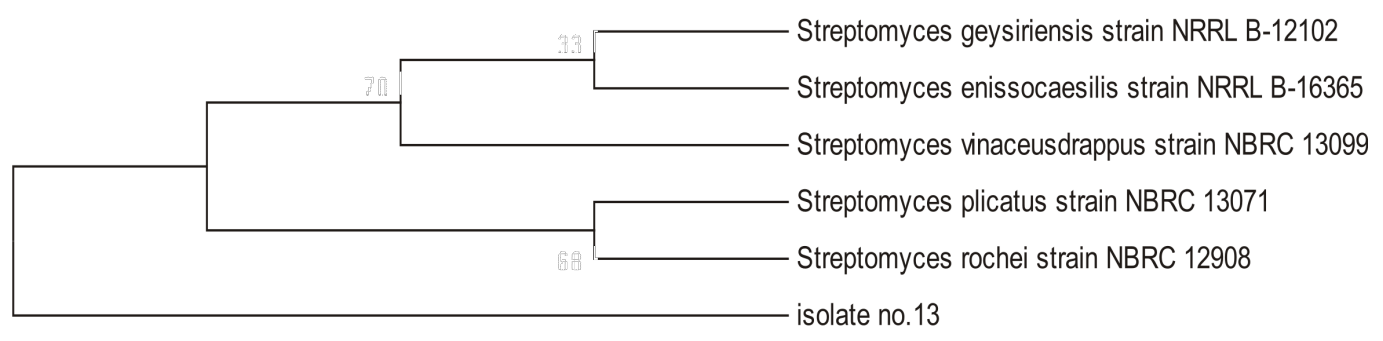

b)

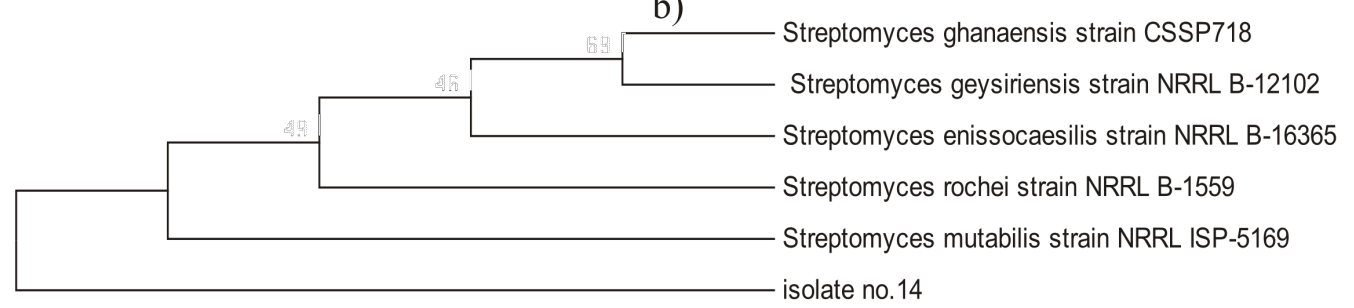

c)

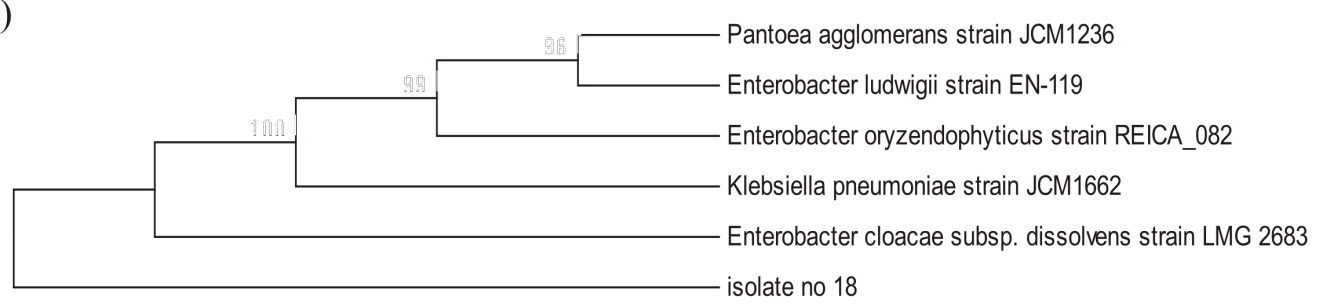

d)

Fig. 3. Phylogenetic tree based on $16 \mathrm{~S}$ rDNA sequence using neighbor joining tree method, bootstrap method as a test of phylogeny with 500 bootstrap replications and Kimura 2- parameter model in the Molecular Evolution Genetic Analysis (MEGA) software version 6
a) phylogenetic tree of isolate no. 16 with maximum sequence difference $=0.05$
b) phylogenetic tree of isolate No. 13 with maximum sequence difference $=0.005$
c) phylogenetic tree of isolate No. 14 with maximum sequence difference $=0.005$
d) phylogenetic tree of isolate No. 18 with maximum sequence difference $=0.005$ 


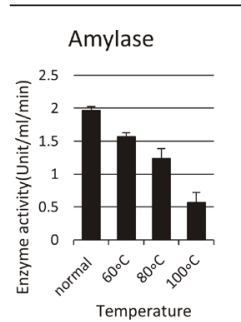

(a)

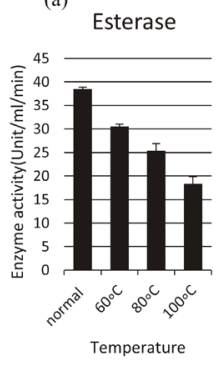

(d)

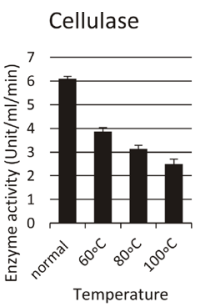

(b)

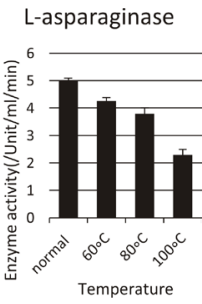

(c)

Caseinase

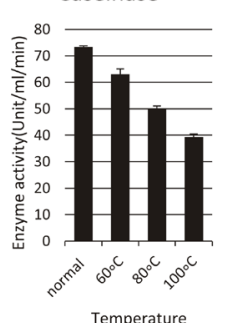

(e)

Fig. 4. The stability profile of various enzymes produced from different isolates at various temperatures (normal assay condition, $60^{\circ} \mathrm{C}, 80^{\circ} \mathrm{C}$, and $100^{\circ} \mathrm{C}$ ). (a) For amylase (Streptomyces mutabilis), (b) For cellulase (Streptomyces ghanaensis), (c) For L- asparaginase (Enterobacter cloacae), (d) For esterase (Streptomyces ghanaensis) and (e) For caseinase (Streptomyces rochei)

Sequences were analyzed using neighborjoining method ${ }^{36}$. Phylogeny relationship of closely related microorganisms is shown in Fig. 3.

Screening of the enzymes stability at different temperatures

The stability of enzymes of selected strains at various temperatures $\left(60^{\circ} \mathrm{C}, 80^{\circ} \mathrm{C}, 100^{\circ} \mathrm{C}\right)$ were shown in Fig. 4.

After exposure to different temperatures $\left(60^{\circ} \mathrm{C}, 80^{\circ} \mathrm{C}, 100^{\circ} \mathrm{C}\right)$, all 5 enzymes still show a good activity, for amylase; the activity was $(1.5,1.2$, $0.5 \mathrm{U} / \mathrm{ml} / \mathrm{min})$, for cellulase; $(3.8,3.1,2.5 \mathrm{U} / \mathrm{ml}$ / $\mathrm{min})$, for L-asparaginase $(4.2,3.8,2.3 \mathrm{U} / \mathrm{ml} / \mathrm{min})$, for esterase; $(30.5,25.3,18.3 \mathrm{U} / \mathrm{ml} / \mathrm{min})$, and for caseinase $(63,50,39.3 \mathrm{U} / \mathrm{ml} / \mathrm{min})$ respectively.

\section{Quantitative determination of enzyme activity}

The four bacterial isolates were grown in specified liquid broth and the concentrations of enzyme production were determined in the cell-free supernatant. The enzyme activity under normal quantitative assay conditions for amylase from Streptomyces mutabilis was (1.96 $\mathrm{U} / \mathrm{ml} / \mathrm{min}$ ), for cellulase from Streptomyces ghanaensis was $(6.1 \mathrm{U} / \mathrm{ml} / \mathrm{min})$, for L-asparaginase from Enterobacter cloacae was (5U/ml/min), for esterase from Streptomyces ghanaensis was $(38.46 \mathrm{U} / \mathrm{ml} / \mathrm{min})$, and for caseinase from Streptomyces rochei was (73.33U/ml/min).

Optimum condition for enzyme activity at different (temperature, pH, salinity, and normality)

Amylase from Streptomyces mutabilis

Temperature, $\mathrm{NaCl}$, and $\mathrm{pH}$ have a profound effect on enzymatic activity. The fermented extract exhibited optimum temperature for amylase activity $(4.96 \mathrm{U} / \mathrm{ml} / \mathrm{min})$ at $100^{\circ} \mathrm{C}$, while the activity was $(3.03 \mathrm{U} / \mathrm{ml} / \mathrm{min})$ at $60^{\circ} \mathrm{C}$ under normal assay conditions.

Maximum enzyme activity was observed at $\mathrm{pH} 5(3.96 \mathrm{U} / \mathrm{ml} / \mathrm{min})$, and the use of more alkaline buffer resulted in a sharp decline of enzyme activity.

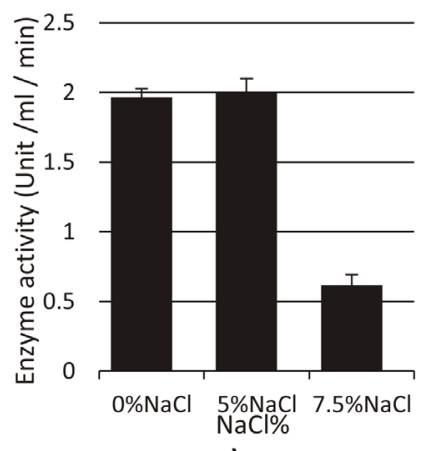

a)

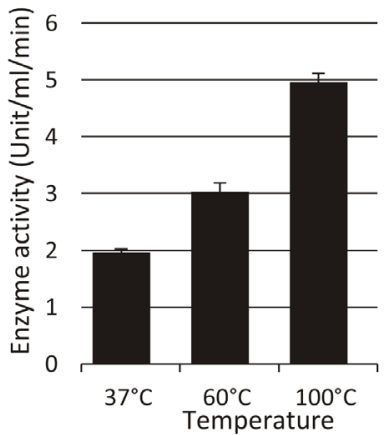

b)

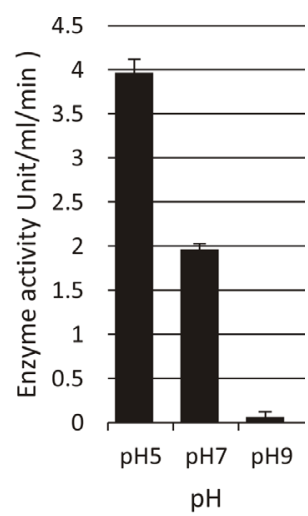

c)

Fig. 5. Effect of different factors (a: $\mathrm{NaCl} \%$, b: Temperature, c: $\mathrm{pH}$ ) on the activity of amylase enzyme from Streptomyces mutabilis 


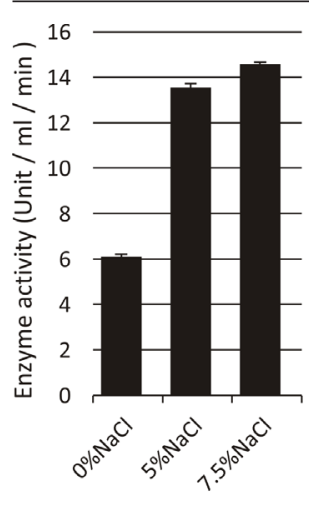

a)

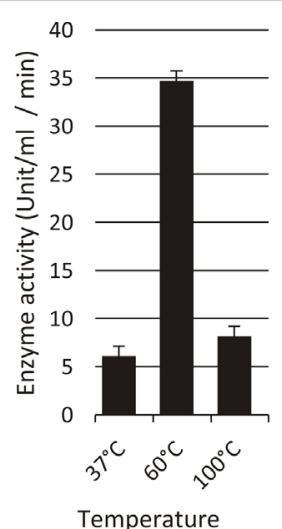

b)

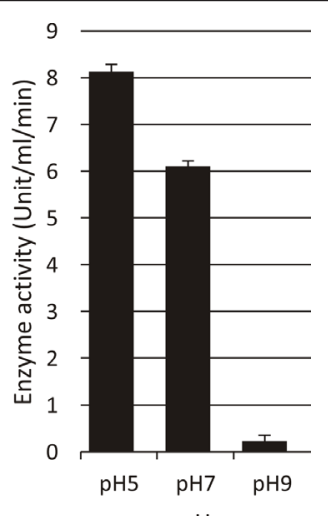

c)

Fig. 6. Effect of different factors (a: $\mathrm{NaCl} \%$, b: Temperature, c: $\mathrm{pH}$ ) on the activity of cellulase enzyme from Streptomyces ghanaensis

Highest enzyme activity was shown in (5\%) $\mathrm{NaCl}(2 \mathrm{U} / \mathrm{ml} / \mathrm{min})$ and $(0.61 \mathrm{U} / \mathrm{ml} / \mathrm{min})$ in $7.5 \% \mathrm{NaCl}$. (Fig. 5).

\section{Cellulase from Streptomyces ghanaensis}

The effect of temperature on the activity of crude cellulase obtained from culture supernatant was determined at various temperatures $\left(37^{\circ} \mathrm{C}\right.$, $60,100^{\circ} \mathrm{C}$ ) at pH 7.0 (Fig. 6). The enzyme showed a good activity at $100^{\circ} \mathrm{C}(2.08 \mathrm{U} / \mathrm{ml} / \mathrm{min})$ with maximum activity at $60^{\circ} \mathrm{C}(8.4 \mathrm{U} / \mathrm{ml} / \mathrm{min})$. The enzyme has optimal activity at pH $5(1.96 \mathrm{U} / \mathrm{ml} /$ min) with severe decline in activity at $\mathrm{pH} 9$.

For determination of suitable $\mathrm{NaCl}$ concentration for enzymatic activity, enzyme assay was done at different $\mathrm{NaCl} \%(0 \%, 5 \%$, $7.5 \%)$. Maximum enzyme activity was observed at $7.5 \% \mathrm{NaCl}(3.66 \mathrm{U} / \mathrm{ml} / \mathrm{min})$ at $37^{\circ} \mathrm{C}, \mathrm{pH} 7$. and at $5 \% \mathrm{NaCl}$ is $(3.3 \mathrm{U} / \mathrm{ml} / \mathrm{min})$.
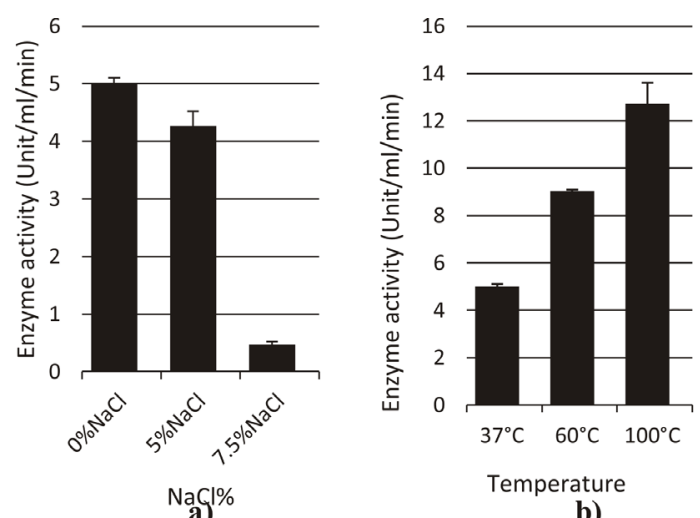

b)

\section{L-asparaginase from Enterobacter cloacae}

The optimum temperatures for L-asparaginase activity was at $100^{\circ} \mathrm{C}(12.73 \mathrm{U} /$ $\mathrm{ml} / \mathrm{min})$, and at $60^{\circ} \mathrm{C}$ was $(9.03 \mathrm{U} / \mathrm{ml} / \mathrm{min})$ under normal assay conditions as shown in Fig. 7.

The enzyme activity was optimum at $\mathrm{pH} 9$ $(5 \mathrm{U} / \mathrm{ml} / \mathrm{min})$, and the activity was $(3.2 \mathrm{U} / \mathrm{ml} / \mathrm{min})$ at $\mathrm{pH} 5$ under normal assay conditions.

The enzyme exhibited optimum L-asparaginase activity at $5 \% \mathrm{NaCl}(4.2 \mathrm{U} / \mathrm{ml} / \mathrm{min})$, and the enzyme activity was $(0.46 \mathrm{U} / \mathrm{ml} / \mathrm{min})$ at $7.5 \% \mathrm{NaCl}$ under normal assay conditions

\section{Esterase from Streptomyces ghanaensis}

Optimum temperature for esterase activity was in the normal condition of assay, while the activity decrease by increasing temperature $(20.9 \mathrm{U} / \mathrm{ml} / \mathrm{min})$ at $60^{\circ} \mathrm{C}$ and $(17.4 / \mathrm{ml} / \mathrm{min})$ at $100^{\circ} \mathrm{C}$

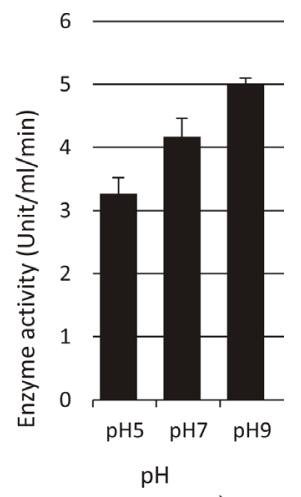

c)

Fig. 7. Effect of different factors (a:NaCl\%, b: Temperature, c: $\mathrm{pH}$ ) on activity of L-asparaginase enzyme from Enterobacter cloacae 


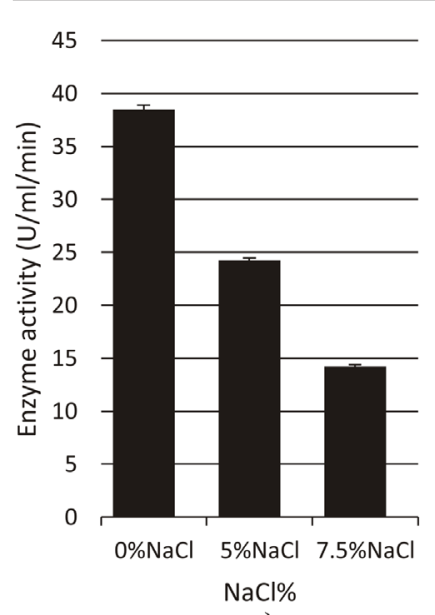

a)

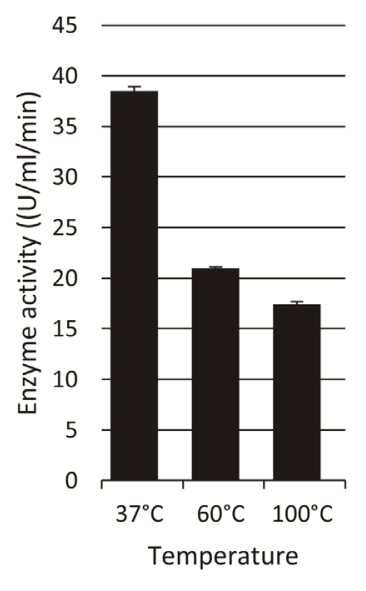

b)

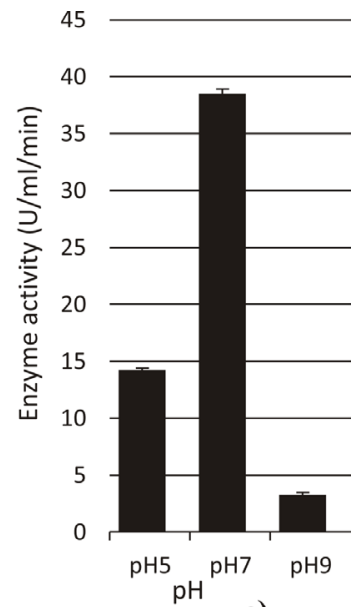

c)

Fig. 8. Effect of different factors (a: $\mathrm{NaCl} \%$, b: Temperature, c: $\mathrm{pH}$ ) on activity of esterase enzyme from Streptomyces ghanaensis

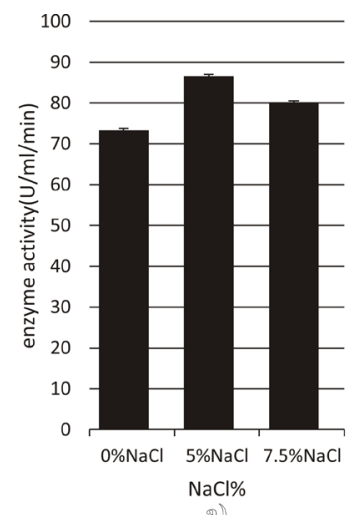

D)

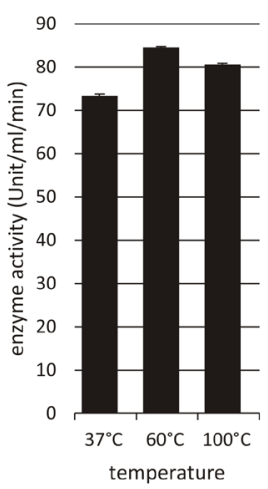

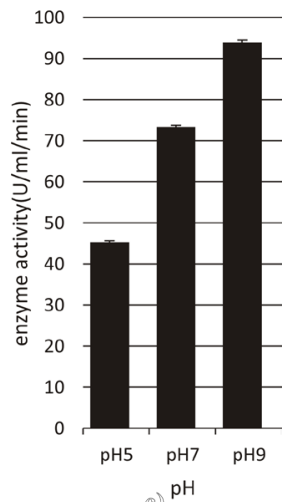

$\mathrm{pH}$

Fig. 9. Effect of different factors (a: $\mathrm{NaCl} \%$, b: Temperature, $\mathbf{c}: \mathrm{pH}$ ) on activity of Caseinase enzyme from Streptomyces rochei

Enzyme activity was $(14.2 \mathrm{U} / \mathrm{ml} / \mathrm{min})$ at $\mathrm{pH} 5$, and the use of more alkaline buffer resulted in a decline of the activity $(3.2 \mathrm{U} / \mathrm{ml} / \mathrm{min})$ under normal assay conditions.

The enzyme activity was $(24.2,14.2 \mathrm{U} / \mathrm{ml} /$ $\mathrm{min}$ ) in $5 \%, 7.5 \% \mathrm{NaCl}$ respectively under normal assay conditions. (Fig. 8)

\section{Caseinase from Streptomyces rochei}

The enzyme showed a better activity at $60^{\circ} \mathrm{C}$, and $100^{\circ} \mathrm{C}(84.5,80.6 \mathrm{U} / \mathrm{ml} / \mathrm{min})$ respectively when compared to $37^{\circ} \mathrm{C}$.

The enzyme has with optimal activity at $\mathrm{pH} 9(93.9 \mathrm{U} / \mathrm{ml} / \mathrm{min})$, and this activity decreased to the half $(45.2 / \mathrm{ml} / \mathrm{min})$ at $\mathrm{pH} 5$ under normal assay conditions.

Maximum enzyme activity was observed at $5 \% \mathrm{NaCl}(86.6 \mathrm{U} / \mathrm{ml} / \mathrm{min})$ at $37^{\circ} \mathrm{C}$. activity at $7.5 \% \mathrm{NaCl}$ is $80.1 \mathrm{U} / \mathrm{ml} / \mathrm{min}$ under normal assay conditions. (Fig. 9)

\section{DISCUSSION}

The study of enzyme activities in soil had large fields of interest for eighty years; however, it was only since the early 1950's that it had developed into a significant research topic in soil microbiology and biochemistry. Soil microorganisms including bacteria secrete extracellular enzymes for the degradation of organic matter ${ }^{37}$.

Actinomycetes are potential producers of different biologically active enzymes. Previous studies show that Actinomycetes had gained enormous importance as they have a capacity 
to produce and secrete different extracellular hydrolytic enzymes ${ }^{38,39} \mathrm{~A}$ number of researchers in earlier studies had also, reported that actinomycete from soil and water bodies possess high number of active enzymes. Patke and his colleagues, Chaphalkar and his colleagues had reported protease activity in isolated Actinomycetes ${ }^{40,41}$, Hiroshi Tsujib isolated an alkaline protease from alkalophilic actinomycete, $\mathrm{N}$. dussonrdlri subsp from a soil sample ${ }^{42}$. Abraham and his colleagues, Obi and his colleagues and Williams had reported amylase activity in Actinomycetes ${ }^{43-45}$. For cellulase activity in Actinomycetes; Jeffrey and Azrizal reported about the cellulase production from Streptomyces gancidicus, Streptomyces malachitofuscus isolated from different locations of Peninsular Malaysia ${ }^{46}$. Yugal Kishore; isolated nine isolates of cellulose-degrading Actinomycetes from different sediments ${ }^{47}$, Manuel veiga found cellulolytic activity in Actinomycetes isolated from marine sediments ${ }^{48}$. L-asparaginase activity was reported by Neelima, Amena S.and Dhanam Jayam ${ }^{19,49,50}$, and esterase activity was reported by Demirjian and his colleagues, Ramnatha and his colleagues and Tirawongsaroj and his colleagues $20,51,52$.

In our study, almost all isolates possess more than one activity, in which the isolates showed the ability to produce a wide range of enzymes. This could be attributed to the phenomena of natural selection of microorganisms in order to survive in the competing environment 53. Earlier studies had also, proved that marine Actinomycetes are exhibiting diverse patterns in secreting extracellular enzymes ${ }^{5,54}$.

In the present study, all the isolated strains were tested for their cellulase, L-asparaginase, esterase, amylase and protease activities. The enzymatic activities of the isolated strains revealed that out of 26 Actinomycetes 10 (45\%), 8 (36\%), $15(68 \%), 5(22 \%)$, and 7 (32\%) were possessing cellulase, L-asparaginase, esterase, amylase and protease activity respectively. Out of 12 Eubacteria strains $6(60 \%), 4(40 \%)$, and 9 (90\%), $5(40 \%)$, and 7 (70\%) were possessing cellulase, L-asparaginase, esterase, amylase and protease activity respectively.

According to T.Ashokvardhan; it was found that among the 25 Actinomycetes, 96\% (24 strains) were amylolytic, $88 \%$ were proteolytic and
$44 \%$ (11 strains) exhibited lipolytic activity ${ }^{55}$, Payal found that during primary screening, a total of 80$90 \%$ isolates showed cellulase activity ${ }^{8}$, Mohanta, found $18 \%$ isolates as cellulase producing organism 47 .

Gulve found that out of 90 Actinomycetes 76 (84.44\%), 70 (77.78\%), 65 (72.22\%), 39 (43.33\%), 34 (37.78\%) and 15 (16.67\%) number of Actinomycetes were possessing protease, gelatinase, amylase, lecithinase, cellulase and urease activity respectively ${ }^{56}$.

The enzyme activity of the 26 Actinomycetes, 12 Eubacteria varied from isolate to isolate depending upon the growth and physical condition of the isolates. This difference may be due to the nature of the sample from which they isolated. Mukesh Sharma also, reported that biological functions of Actinomycetes mainly depend on the sources from which the bacteria were isolated ${ }^{57}$.

Thermostable cellulase was reported to be produced from Streptomyces genus by Hung-Der ${ }^{58}$. According to Vieille, amylase from Pyrococcus furiosus, was stable at higher temperatures $80-100{ }^{\circ} \mathrm{C}{ }^{59}$. According to Pant and his colleagues, Residual protease activity was determined at different temperatures and was maximal at $40-50{ }^{\circ} \mathrm{C}^{28}$. According to Tirawongsaroj, the Esterase displayed high thermal stability at temperatures up to $70^{\circ} \mathrm{C}^{52}$. However according to Amena the L-asparaginase enzyme retained 55\% of the activity, at $80^{\circ} \mathrm{C}$, it was maximally active at $40^{\circ} \mathrm{C}{ }^{49}$. This optimum L-asparaginase activity at $40^{\circ} \mathrm{C}$ was similar to that of Corynebacterium glutamicum, reported by Mesas ${ }^{60}$.

Results of some of these enzymes indicated the thermostable nature, which is an important desired characteristic that suits its applicability in various enzyme based industries. $\mathrm{pH}$ is one of the important factors that determine the growth and enzyme secretion of microorganisms as they are sensitive to the concentration of hydrogen ions present in the medium. High enzyme titer was attained when the initial $\mathrm{pH}$ of the assay was maintained at 5 for amylase and cellulase enzymes produced from Streptomyces mutabilis and Streptomyces ghanaensis respectively.

Two strains show maximum activity of the enzymes at $\mathrm{pH}$ 9; L-asparaginase and caseinase produced from Enterobacter cloacae 
and Streptomyces rochei respectively. Two strains (Streptomyces ghanaensis and Enterobacter cloacae) had maximum esterase, l-asparaginase activity respectively near neutrality.

In 2009, Haddar reported that the optimum $\mathrm{pH}$ of alkaline serine proteases (BM1) from Bacillus mojavensis was between 8.0 and 10.0, while $\mathrm{BM} 2$ was maximally active at $\mathrm{pH} 10.0$ 61. Rahna found that the cellulase enzyme shows high activity at a broad range of $\mathrm{pH}$ values $(\mathrm{pH} 4-6)$ with optimal $\mathrm{pH}$ at $5.0^{62}$. According to Amena; the optimal $\mathrm{pH}$ determined for L-asparaginase activity of Streptomyces gulbargensis was $9.0^{49}$. Subha has reported similar observations for asparaginase from Pseudomonas stutzeri. ${ }^{63}$.

According to Maya; it was found that most Bacillus spp. produce lipolytic enzymes that have optimum activity at neutral or moderately alkaline $\mathrm{pH}(\mathrm{pH}=8.0-10.0)^{64}$. While, Olukayode reported that the partially purified enzyme preparations of Bacillus licheniformis had $\mathrm{pH}$ optimum activity at $5.5^{12}$.

In this study, temperature have profound effect on enzymatic activity. This is due to the increase of kinetic energy and velocity that follows temperature increases. With high velocity, less time between collisions will be, that led to more molecules that reaches the activation energy, which increases the rate of the reactions. Since the molecules are moving faster, collisions will increase between enzymes and substrates. ${ }^{9}$

We found that four isolates show high enzyme activity at higher temperatures. With optimum activity at $60^{\circ} \mathrm{C}$ for cellulase, caseinase, and at $100^{\circ} \mathrm{C}$ for amylase, L-asparaginase.

However, esterase is a thermostable enzyme; the optimum activity was observed at $37^{\circ} \mathrm{C}$.

Amylase was bio-synthesized using a thermophilic bacterium Bacillus sp. This enzyme had been reported to display its optimal activity at a remarkably high temperature of $70^{\circ} \mathrm{C}$, a species of Bacillus stearothermophilus TP26 that has been isolated produces an extra cellular protease having an optimum temperature of $75^{\circ} \mathrm{C} 65$.

According to Dhevagi; at $80^{\circ} \mathrm{C}$, L-asparaginase show $85 \%$ of its activity ${ }^{66}$. According to Tirawongsaroj, the effect of temperature on Esterase activity was determined and showed highest activity at $70^{\circ} \mathrm{C}^{52}$. Optimum temperature range of cellulases activity of $80-100{ }^{\circ} \mathrm{C}$ had been reported for enzymes isolated from several archaebacteria ${ }^{67}$.

Effect of salinity on enzyme activity was measured for all the enzymes in the current study. It was founded that two enzymes have optimum activity at $0 \% \mathrm{NaCl}$, esterase, L-asparaginase produced from Streptomyces ghanaensis and Enterobacter cloacae. Two enzymes amylase, caseinase produced from Streptomyces mutabilis and Streptomyces rochei respectively show optimum activity at $5 \%$, while cellulase produced from Streptomyces ghanaensis with optimum activity at $7.5 \% \mathrm{NaCl}$. L-asparaginase activity of Enterobacter cloacae not affected with $5 \% \mathrm{NaCl}$.

Xiao Ting $\mathrm{Fu}$ found that relative activity of the protease was 73,33 , and $5 \%$ at 10,20 , and $30 \% \mathrm{NaCl}$ concentrations respectively ${ }^{68}$. Ajay found that the amylase retains more than $60 \%$ of the initial activity even at $\mathrm{NaCl}$ concentration of $3.5 \mathrm{M}(20 \%)^{69}$. Susan found that Mucor-originated L-asparaginase activity was unaffected by the addition of $4 \%(\mathrm{w} / \mathrm{v}) \mathrm{NaCl}{ }^{70}$. Tianchen showed that the activity of Cellulase was moderately improved in the presence of $0.5-1 \mathrm{M} \mathrm{NaCl}$ and when $\mathrm{NaCl}$ concentration was progressively increased up to $4 \mathrm{M}$, the activity remained unchanged ${ }^{71}$.

\section{CONCLUSION}

In this study, 38 strains were isolated and analyzed in relation to their ability to produce extracellular enzymes. Large numbers of recovered isolates have wide diversity for production of potential industrial enzymes (amylase, cellulase, L-asparaginase, esterase and caseinase). Three Actinomycetes and one eubacterium isolates bear extremophilic properties (thermostable alkaliphilic and acidophilic). Extraordinary characteristics of such enzymes make them a promising renewable tools for industrial biotechnological process.

\section{ACKNOWLEDGMENTS}

H.R.T. is grateful to Dr Sameh Mohamed Mohamedi in Microbiology Department, Faculty of Pharmacy, Beni-Suef University for helping us in grammar check and plagiarism check, and great thank to Dr Eman Gouda in Biotechnology and Life Sciences Department Faculty of PSAS, Beni-Suef University for helping in revising the paper and for her valuable suggestions throughout the study. 


\section{REFERENCES}

1. Abd-Elhalem, B. T.; El-Sawy, M.; Gamal, R. F.; Abou-Taleb, K. A. Production of Amylases from Bacillus Amyloliquefaciens under Submerged Fermentation Using Some Agro-Industrial byProducts. Ann. Agric. Sci. 2015, 60 (2), 193-202.

2. Haki, G. D.; Rakshit, S. K. Developments in Industrially Important Thermostable Enzymes: A Review. Bioresour. Technol. 2003, 89 (1), 17-34.

3. Adrio, J. L.; Demain, A. L. Microbial Enzymes: Tools for Biotechnological Processes. Biomolecules 2014, 4 (1), 117-139.

4. Bhaturiwala, R. A.; Jha, S. C.; Jain, N. K.; Modi, H. A. Enzyme Profiling of Selected Chitinase Producing Actinomycetes. Eur. J. Biotechnol. Biosci. 2017, 5 (1), 39-43.

5. Lekshmi, M., A. J. Isolation and Screening of Actinomycetes from Marine Sample. Int. J. Sci. Eng. Res. 2016, 2 (5), 1-7.

6. Singh, R.; Kumar, M.; Mittal, A.; Mehta, P. K. Microbial Enzymes: Industrial Progress in 21st Century. 3 Biotech 2016, 6 (2), 174.

7. Zhang, S.-B.; Wu, Z.-L. Identification of Amino Acid Residues Responsible for Increased Thermostability of Feruloyl Esterase A from Aspergillus niger Using the PoPMuSiC Algorithm. Bioresour. Technol. 2011, 102 (2), 2093-2096.

8. Das, P.; Solanki, R.; Khanna, M. Isolation and Screening of Cellulolytic Actinomycetes from Diverse Habitats. Int. J. Adv. Biotechnol. Res. 2014, 5, 976-2612.

9. Nigam, P. S. Microbial Enzymes with Special Characteristics for Biotechnological Applications. Biomolecules 2013, 3 (3), 597-611.

10. Ogawa, J.; Shimizu, S. Microbial Enzymes: New Industrial Applications from Traditional Screening Methods. Trends Biotechnol. 1999, 17 (1), 13-20.

11. Length, F. Isolation, Optimization and Characterization of Protease Producing Bacteria from Soil and Water in Gondar. Int. J. Bacteriol. Virol. Immunol. 2014, 1 (3), 20-24.

12. Amund, O. O.; Ogunsina, O. A. Extracellular Amylase Production by Cassava-Fermenting Bacteria. J. Ind. Microbiol. 1987, 2 (2), 123-127.

13. Raul, D.; Biswas, T.; Mukhopadhyay, S.; Kumar Das, S.; Gupta, S. Production and Partial Purification of Alpha Amylase from Bacillus Subtilis (MTCC 121) Using Solid State Fermentation. Biochem. Res. Int. 2014.

14. Simair, A. A.; Khushk, I.; Qureshi, A. S.; Bhutto, M. A.; Chaudhry, H. A.; Ansari, K. A.; Lu, C. Amylase Production from Thermophilic Bacillus Sp. BCC 021-50 Isolated from a Marine Environment. Fermentation 2017, 3 (2), 25.
15. Aruwajoye, G. S.; Omoboye, O. O.; Daramola, I. O.; Agboola, K. Extracellular Cellulase Production by Bacillus Circulans Isolated from Decayed Wood. 2014, 3 (2), 1-8.

16. Sethi, S.; Datta, A.; Gupta, B. L.; Gupta, S. Optimization of Cellulase Production from Bacteria Isolated from Soil. ISRN Biotechnol. 2013, 2013.

17. Mahajan, R. V; Saran, S.; Saxena, R. K.; Srivastava, A. K. A Rapid, Efficient and Sensitive Plate Assay for Detection and Screening of I-AsparaginaseProducing Microorganisms. FEMS Microbiol. Lett. 2013, 341 (2), 122-126.

18. Shukla, D.; Shrivastav, V. K.; Jana, A. M.; Shrivastav, A. Exploration of the Potential L-Asparaginase Producing Bacteria from the Soil of Gwalior (India). Int. J. Curr. Microbiol. Appl. Sci 2014, 3, 665-672.

19. Deshpande, N.; Choubey, P.; Agashe, M. Studies on Optimization of Growth Parameters for L-Asparaginase Production by Streptomyces Ginsengisoli. Sci. World J. 2014, 2014.

20. Ramnath, L.; Sithole, B.; Govinden, R. Identification of Lipolytic Enzymes Isolated from Bacteria Indigenous to Eucalyptus Wood Species for Application in the Pulping Industry. Biotechnol. Reports 2017, 15, 114-124.

21. Samad, N. S. A. Isolation and Identification of Halophilic Bacteria Producing Halotolerant Protease. 2017.

22. Singh, R. N.; Bahuguna, A.; Chauhan, P.; Sharma, V. K.; Kaur, S.; Singh, S. K.; Khan, A. Production, Purification and Characterization of Thermostable $\$ \pm \$$-Amylase from Soil Isolate Bacillus Sp. Strain B-10. J. Biosci. Biotechnol. 2016, 5 (1).

23. Detns, R. C.; Taken, S.; Co, F. S.; Smith, F.; Co, C.; Titrim-, F. Use of Dinitrosalicylic Acid Reagent for Determination of Reducing Sugar. No. III.

24. Ibrahim, A. S. S.; El-diwany, A. I. Isolation and Identification of New Cellulases Producing Thermophilic Bacteria from an Egyptian Hot Spring and Some Properties of the Crude Enzyme. Aust. J. Basic Appl. Sci. 2007, 1 (4), 473-478.

25. Dange, V. U.; Peshwe, S. A. Screening and Characterization of Actinomycetes for Production of Anti-Leukemic L-Asparaginase. Indian J. Appl. Res. 2013, 3 (7), 543-545.

26. Tahir, L.; Ali, M. I.; Zia, M.; Atiq, N.; Hasan, F.; Ahmed, S. Production and Characterization of Esterase in Lantinus Tigrinus for Degradation of Polystyrene. 2013, 62 (1), 101-108.

27. Sayali, K.; Sadichha, P.; Surekha, S. Microbial 
Esterases: An Overview. Int. J. Curr. Microbiol. Appl. Sci 2013, 2, 135-146.

28. Pant, G.; Prakash, A.; Pavani, J. V. P.; Bera, S.; Deviram, G. V. N. S.; Kumar, A.; Panchpuri, M.; Gyana, R. Production, Optimization and Partial Purification of Protease from Bacillus Subtilis. Integr. Med. Res. 2015, 9 (1), 50-55.

29. Kuberan, T.; Sangaralingam, S.; Thirumalaiarasu, V. Isolation and Optimization of Protease Producing Bacteria from Halophilic Soil. J. Biosci. Res 2010, 1 (3), 163-174.

30. El Hadj-Ali, N.; Agrebi, R.; Ghorbel-Frikha, B.; Sellami-Kamoun, A.; Kanoun, S.; Nasri, M. Biochemical and Molecular Characterization of a Detergent Stable Alkaline Serine-Protease from a Newly Isolated Bacillus Licheniformis NH1. Enzyme Microb. Technol. 2007, 40 (4), 515-523.

31. Madden, T. L.; Tatusov, R. L.; Zhang, J. [9] Applications of Network BLAST Server. In Methods in enzymology; Elsevier, 1996; Vol. 266, pp 131-141.

32. Saitou, N.; Nei, M. The Neighbor-Joining Method: A New Method for Reconstructing Phylogenetic Trees. Mol. Biol. Evol. 1987, 4 (4), 406-425.

33. Dopazo, J. Estimating Errors and Confidence Intervals for Branch Lengths in Phylogenetic Trees by a Bootstrap Approach. J. Mol. Evol. 1994, 38 (3), 300-304.

34. Kimura, M. A Simple Method for Estimating Evolutionary Rates of Base Substitutions through Comparative Studies of Nucleotide Sequences. J. Mol. Evol. 1980, 16 (2), 111-120.

35. Tamura, K.; Stecher, G.; Peterson, D.; Filipski, A.; Kumar, S. MEGA6: Molecular Evolutionary Genetics Analysis Version 6.0. Mol. Biol. Evol. 2013, 30 (12), 2725-2729.

36. Weisburg, W. G.; Barns, S. M.; Pelletier, D. A.; Lane, D. J. 16S Ribosomal DNA Amplification for Phylogenetic Study. J. Bacteriol. 1991, 173 (2), 697-703.

37. Burns, R. G. Enzyme Activity in Soil: Location and a Possible Role in Microbial Ecology. Soil Biol. Biochem. 1982, 14 (5), 423-427.

38. Saadoun, I.; Rawashdeh, R.; Dayeh, T.; Ababneh, Q.; Mahasneh, A. Isolation, Characterization and Screening for Fiber Hydrolytic EnzymesProducing Streptomycetes of Jordanian Forest Soils. Biotechnology 2007, 6 (1), 120-128.

39. Tan, H.; Deng, Z.; Cao, L. Isolation and Characterization of Actinomycetes from Healthy Goat Faeces. Lett. Appl. Microbiol. 2009, 49 (2), 248-253.

40. Patke, D. S. Characterization of Enzyme and Genetic Studies of Thermophilic Streptomycetes., 1996, Vol. 5.

41. Ravindra Chaphalkar, S. Studies of Industrially
Important Streptomyces with Special Reference to Extracellular Protease. Design 1993, No. February, 67.

42. Tsujibo, H.; Miyamoto, K.; Hasegawa, T.; Inamori, Y. Purification and Characterization of Two Types of Alkaline Serine Proteases Produced by an Alkalophilic Actinomycete. J. Appl. Bacteriol. 1990, 69 (4), 520-529.

43. Abraham T.A. and Herr L.J. Activity of Actinomycetes from Rhizosphere and NonRhizosphere Soils of Corn and Soybean in Four Physiological Tests. Can. J. Microbiol. 10, 281285. 1964, 10 (35).

44. Obi, S. K. C.; Odibo, F. J. C. Some Properties of a Highly Thermostable A-Amylase from a Thermoactinomyces Sp. Can. J. Microbiol. 1984, 30 (6), 780-785.

45. Williams, S. T.; Goodfellow, M.; Alderson, G.; Wellington, E. M. H.; Sneath, P. H. A.; Sackin, M. J. Numerical Classification of Streptomyces and Related Genera. Microbiology 1983, 129 (6), 1743-1813.

46. Jeffrey, L. S. H.; Azrizal, M. R. Screening for Cellulase Activities in Actinomycetes Isolated from Different Locations of Peninsular Malaysia. J. Trop. Agric. Fd. Sc. 2007, 35 (1), 153-157.

47. Mohanta, Y. K. Isolation of Cellulose-Degrading Actinomycetes and Evaluation of Their Cellulolytic Potential. Bioeng. Biosci. 2014, 2 (1), 1-5.

48. Veiga, M.; Esparis, a; Fabregas, J. Isolation of Cellulolytic Actinomycetes from Marine Sediments. Appl. Environ. Microbiol. 1983, 46 (1), 286-287.

49. Amena, S. Production, Purification and Characterization of I-Asparaginase From. Brazilian J. Microbiol. 2010, 41 (1), 173-178.

50. Dhanam Jayam, G., S. K. Screening and Characterization of L-Asparaginase Producing Streptomyces Isolated From Soil Samples of Periyar Lake, Kumily. Biosci. Discov. 2014, 5 (1), 50-54.

51. Demirjian, D. C.; Morís-Varas, F.; Cassidy, C. S. Enzymes from Extremophiles. Curr. Opin. Chem. Biol. 2001, 5 (2), 144-151.

52. Tirawongsaroj, P.; Sriprang, R.; Harnpicharnchai, P.; Thongaram, T.; Champreda, V.; Tanapongpipat, S.; Pootanakit, K.; Eurwilaichitr, L. Novel Thermophilic and Thermostable Lipolytic Enzymes from a Thailand Hot Spring Metagenomic Library. J. Biotechnol. 2008, 133 (1), 42-49.

53. Boroujeni, M. E.; Das, A.; Prashanthi, K.; Suryan, S.; Bhattacharya, S. Enzymatic Sceening and Random Amplified Polymorphic DNA Fingerprinting of Soil Streptomycetes Isolated 
from Wayanad District in Kerala, India. J. Biol. Sci. 2012, 12 (1), 43-50.

54. Ramesh, S.; Mathivanan, N. Screening of Marine Actinomycetes Isolated from the Bay of Bengal, India for Antimicrobial Activity and Industrial Enzymes. World J. Microbiol. Biotechnol. 2009, 25 (12), 2103-2111.

55. Ashokvardhan, T.; Rajithasri, A. B.; Prathyusha, P.; Satyaprasad, K. Original Research Article Actinomycetes from Capsicum Annuum L. Rhizosphere Soil Have the Biocontrol Potential against Pathogenic Fungi. Int. J. Curr. Microbiol. App. Sci 2014, 3 (4), 894-903.

56. Gulve, R. M., A. M. D. Enzymatic Activity of Actinomycetes Isolated from Marine Sedimentes. Sci. Technol. 2011, 3 (5), 15-17.

57. Sharma, M.; Dangi, P.; Choudhary, M. Actinomycetes/: Source, Identification, and Their Applications. Int J Curr Microbiol App Sci 2014, 3 (2), 801-832.

58. Jang, H. Der; Chang, K. S. Thermostable Cellulases from Streptomyces Sp.: Scale-up Production in a 50-I Fermenter. Biotechnol. Lett. 2005, 27 (4), 239-242.

59. Vieille, C.; Zeikus, G. J. Hyperthermophilic Enzymes: Sources, Uses, and Molecular Mechanisms for Thermostability. Microbiol. Mol. Biol. Rev. 2001, 65 (1), 1-43.

60. Mesas, J. M.; Gil, J. A.; Mart n, J. F. Characterization and Partial Purification of L-Asparaginase from Corynebaeterium Glutamicurn. J. Gen. Microbiol. 1990, 136 (3), 515-519.

61. Haddar, A.; Agrebi, R.; Bougatef, A.; Hmidet, N.; Sellami-Kamoun, A.; Nasri, M. Two Detergent Stable Alkaline Serine-Proteases from Bacillus Mojavensis A21: Purification, Characterization and Potential Application as a Laundry Detergent Additive. Bioresour. Technol. 2009, 100 (13), 3366-3373.

62. Rathnan, Rahna K, A. M. Cellulase Enzyme Production by Streptomyces Sp Using Fruit Waste as Substrate. Aust. J. Basic Appl. Sci. 2011,
5 (12), 1114-1118.

63. Manna, S.; Sinha, A.; Sadhukhan, R.; Chakrabarty, S. L. Purification, Characterization and Antitumor Activity of I-Asparaginase Isolated from Pseudomonas Stutzeri MB-405. Curr. Microbiol. 1995, 30 (5), 291-298.

64. Guncheva, M.; Zhiryakova, D. Catalytic Properties and Potential Applications of Bacillus Lipases. J. Mol. Catal. B Enzym. 2011, 68 (1), 1-21.

65. Delatorre, A. B. Microrganismos Termofílicos e Enzimas Termoestáveis de ImportâNcia Comercial. perspectivasonline 2010, 4 (16), 132-145.

66. Dhevagi, P.; Poorani, E. Isolation and Characterization of $\mathrm{L}$-Asparaginase from Marine Actinomycetes. Indian J. Biotechnol. 2006, 5 (December 2003), 514-520.

67. Bragger, J. M.; Daniel, R. M.; Coolbear, T.; Morgan, H. W. Very Stable Enzymes from Extremely Thermophilic Archaebacteria and Eubacteria. Appl. Microbiol. Biotechnol. 1989, 31 (5-6), 556-561.

68. Fu, X. T.; You, S. G.; Kim, S. M. Characterization of a Salt-Tolerant Acid Protease Produced by Bacillus Megaterium KLP-98 and Its Potential as a Fermentation Starter for the Manufacture of Fish Sauce. J. Food Biochem. 2008, 32 (3), 279-298.

69. Singh, A. K. Production, Purification and Characterization of Thermostable Bacterial $\alpha$-amylase by Solid State Fermentation of Agro-Byproducts. Sam Higginbottom Inst. Agric. Technol. Sci. 2016.

70. Fisher, S. H.; Wray, L. V. Bacillus Subtilis 168 Contains Two Differentially Regulated Genes Encoding L-Asparaginase. J. Bacteriol. 2002, 184 (8), 2148-2154.

71. An, T.; Dong, Z.; Lv, J.; Liu, Y.; Wang, M.; Wei, S.; Song, Y.; Zhang, Y.; Deng, S. Purification and Characterization of a Salt-Tolerant Cellulase from the Mangrove Oyster, Crassostrea Rivularis. Acta Biochim. Biophys. Sin. (Shanghai). 2015, 47 (4), 299-305. 